\title{
PENGEMBANGAN E-MODUL (MODUL DIGITAL) DALAM PEMBELAJARAN TEMATIK DI SEKOLAH DASAR
}

\author{
Kuncahyono \\ Universitas Muhammadiyah Malang \\ Email: kuncahyono@umm.ac.id
}

Naskah diterima : 21 September 2018, direvisi : 27 September 2018, disetujui : 18 Oktober 2018

\begin{abstract}
Based on needs analysis, teachers have not fully utilized technology-based media and teaching materials. The teacher also has not fully produced technology-based media and teaching materials. The purpose of this research is to produce practical e-module teaching materials in thematic learning. This research method uses ADDIE research and development model. The results of the study that e-modules were developed through stages of needs analysis, prototype design, prototype development, field testing, and product evaluation. The results showed that practical e-modules were used in learning with a score of $86.5 \%$. Acceptability of the level of independence of e-modules with students achieving eligible criteria is indicated by material support integrated with web-based learning internet links. Based on expert validation, the emodule is suitable to be used as a teaching material for computer-based thematic learning in grade IV elementary school
\end{abstract}

Keywords: development, e-module, thematic learning

Pengutipan: Kuncahyono. (2018). Pengembangan E-Modul (Modul Digital) dalam Pembelajaran Tematik di Sekolah Dasar. JMIE: Journal of Madrasah Ibtidaiyah Education, 2(2), 2018, 219231. jmie.v2i2.75.

Permalink/DOI: http://dx.doi.org/ 10.32934/jmie.v2i2.75 


\section{PENDAHULUAN}

Bahan ajar tidak hanya berupa buku atau LKS yang berbasis media cetak. Bahan ajar berbasis non cetak juga dapat digunakan dalam pembelajaran misalnya dalam bentuk bahan ajar elektronik. Saat ini bahan ajar berbasis elektronik dapat dengan mudah diperoleh karena hadirnya perangkat jaringan teknologi informasi. Melalui jaringan teknologi informasi tersebut guru dapat memanfaatkannya menjadi bahan ajar dengan mudah. Kemudahan dalam mengakses jaringan dan teknologi informasi menjadi kelebihan bagi dunia pendidikan. Dunia pendidikan dapat memanfaatkan sebagai sarana pembelajaran berkemajuan. Pembelajaran tidak hanya bersifat konvensional tetapi juga dapat diintegrasikan melalui daring (dalam jaringan). Melalui pemanfaatan teknologi di kelas menjadikan pembelajaran berdampak positif dan menarik. Hal ini di sesuai dengan hasil riset oleh Arkün (2008:16) yaitu penerapan produk media berbasis teknologi dalam pembelajaran di sekolah menghasilkan dampak positif bagi hasil prestasi belajar siswa. Hasil belajar siswa menjadi lebih baik jika dibandingkan dengan pembelajaran secara tanpa mengunakan sarana teknologi. Hasil lebih lanjut mengungkapkan siswa tertarik dan termotivasi belajar menggunakan media berbasis teknologi.

Menindaklanjuti perkembangan teknologi yang dapat dimanfaatkan dalam pendidikan, terdapat salah satu faktor dalam perkembangan kurikulum pendidikan dasar saat ini yaitu Kurikulum 2013. Dalam kurikulum 2013, pemerintah memberikan gagasan kebijakan bahwa pembelajaran harus didesain secara menarik, holistik, dan membangkitkan motivasi siswa. Pembelajaran dapat diintegrasikan dengan pemanfaatkan teknologi informasi dan komunikasi. Harapan dari pemanfaatan teknologi ini yaitu guru mampu berinovasi dan berkompetensi dalam mengajar, mampu mengembangkan potensi literasi digital, serta mampu meningkatkan kemampuan dalam memanfaatkan teknologi yang ada. Hal ini sejalan dengan pentingnya literasi digital tidak hanya dalam dunia pendidikan, melainkan bagi seluruh masyarakat. Adanya literasi digital diharapkan dapat menata pola pikir masyarakat dan menciptakan iklim kritis kreatif yang tidak mudah termakan isu provokatif, berita hoks, dan korban penipuan berbasis digital (Kemdikbud, 2017).

Ciri khas dalam Kurikulum 2013 selain integrasi teknologi yaitu integrasi pembelajaran tematik. Adapun ciri khas pembelajaran tematik adalah pembelajaran yang memadukan dari berbagai kompetensi antar muatan pelajaran (Prastowo, 2013:223). Peneraan pembelajaran tematik dalam hal ini guru dapat memanfaatkan buku guru dan buku siswa. Namun guru dapat memanfaatkan sarana/media lain 
sebagai bahan ajar yang dapat diterapkan dalam pembelajaran. Salah satu media dan bahan ajar yang dapat digunakan guru dalam pembelajaran tematik yaitu e-modul tematik atau dapat disebut (modul elektronik tematik). E- Modul adalah salah satu produk bahan ajar non cetak berbasis digital yang secara mandiri dirancang untuk dapat dipelajari oleh siswa. E- Modul disebut juga media untuk belajar mandiri karena didalamnya telah dilengkapi dengan petunjuk untuk belajar sendiri. Dapat dikatakan bahwa pembaca dapat melakukan kegiatan pembelajaran tanpa kehadiran pengajar secara langsung (Syamsudin, 2005: 168).

Lebih lanjut dengan menggunakan e-modul menfasilitasi siswa dalam belajarnya baik secara mandiri maupun konvensional. Bahan ajar e-modul dilengkapi petunjuk untuk belajar mandiri, sehingga siswa dapat belajar sesuai dengan kemampuannya. Modul merupakan alat atau sarana yang dapat digunakan sebagai bahan pembelajaran yang berisi materi, metode, batasan-batasan, dan cara mengevaluasi yang dirancang secara sistematis dan menarik untuk mencapai tujuan serta kompetensi yang diharapkan sesuai dengan tingkat kompleksitasnya (Depdiknas, 2008:3).

Hasil studi pendahuluan yang telah dilakukan peneliti bertujuan untuk mengungkap fakta di lapangan terkait sarana teknologi di SD Muhammadiyah 9 Malang. Diketahui bahwa keberadaan fasilitas teknologi dalam pembelajaran juga ditemui di SD Muhammadiyah 9 Malang yang memiliki sarana komputer yang lengkap, ruang kelas yang dilengkapi dengan sarana LCD Proyektor, TV LED, seperangkat komputer personal, dan speaker aktif. Berdasarkan hasil observasi lapangan lanjutan juga terdapat fasilitas teknologi yang perlu mendapat perhatian karena guru masih jarang menggunakan teknologi terutama dalam pembelajaran. Guru lebih dominan memanfaatkan buku guru maupun buku siswa yang sudah tersedia.

Lebih lanjut berdasarkan analisis kebutuhan, tampak bahwa guru kelas IV belum sepenuhnya memanfaatkan media dan bahan ajar berbasis teknologi. Guru juga belum sepenuhnya memproduksi media dan bahan ajar berbasis teknologi. Dilihat dari kondisi siswa saat pembelajaran di kelas menunjukkan rata-rata $70 \%$ siswa tidak menyimak penjelasan guru ditandai dengan siswa bergurau dan berbicara dengan temannya di luar topik materi. Siswa kurang semangat dan kurang antusias dalam menjawab pertanyaan guru. Tampak sekitar 20\% siswa aktif merespon pertanyaan dari guru melalui kegiatan tanya jawab. Berdasarkan fenomena tersebut jika tidak ditindaklanjuti, dimungkinkan akan berdampak pada hasil belajar, motivasi, dan minat siswa. Melihat urgensi terhadap masalah dalam pembelajaran yang telah dipaparkan, 
maka hal tersebut sangat penting untuk dicarikan solusi pemecahan masalah yang terjadi pada pembelajaran tematik di kelas IV. Salah satu solusi dalam mengurangi pola pembelajaran yang bersifat teacher centered dengan memaksimalkan sarana teknologi yaitu melalui pengembangan bahan ajar atau media berbasis teknologi yang dapat memotivasi siswa dalam meningkatkan kualitas hasil belajar.

Senada dengan hal tersebut multimedia tutorial berbasis teknologi membantu membantu dalam mengatasi keterbatasan pembelajaran yang bersifat konvensional, dan mampu memotivasi siswa agar belajar mandiri (Dalal, 2014). Smaldino (2011:14) menyatakan bahwa siswa juga memanfaatkan teknologi dan media untuk meningkatkan mutu dan hasil belajarnya. Lebih lanjut hasil penelitian oleh Jonias (2014) bahwa hasil belajar siswa yang menggunakan media pembelajaran e-module lebih baik dari pada hasil belajar siswa yang tanpa menggunakan media pembelajaran e-module. Berdasarkan deskripsi yang sudah dipaparkan, maka peneliti perlu untuk mengembangkan bahan ajar berbasis teknologi digital e-modul tematik dengan memanfaatkan sarana teknologi yang ada.

\section{METODE PENELITIAN}

Penelitian ini pada dasarnya merupakan penelitian untuk mengembangkan bahan ajar berupa modul yang dapat dikemas dalam bentuk e-modul atau disebut dengan perangkat digital modul (e-modul). Adapun produk yang dikembangkan yaitu produk media pembelajaran e-modul tematik (elektronik modul) tema selalu berhemat energi. Pentingnya penentuan tema berdasarkan dari analisis kebutuhan yang sudah dilakukan bahwa gambaran tema dapat divisualisasikan dengan mudah dengan menggunakan bahan ajar e-modul.

Penelitian ini termasuk R\&D (research and development) dengan menggunakan model penelitian pengembangan ADDIE dengan tahapan dimulai pada siklus (Analysis), siklus produksi terdapat tahap perencangan (design), pengembangan (develop), implementation (penerapan) dan evaluasi (evaluate). Model pengembangan ini dipilih karena sesuai dengan penelitian pengembangan yang menggunakan konsep teknologi dalam membuat produk yaitu e-modul. Selain itu langkah-langkah dalam model ini runtut dan sederhana sampai menghasilkan produk yang dapat diimplementasikan dalam pembelajaran.

Sebagaiman pendapat Pribadi (2011:29) menambahkan alasan lain pemilihan menggunakan model ini karena sederhana dan mudah diimplementasikan oleh guru 
dan perancang program pembelajaran untuk menetapkan pengalaman belajar yang dapat membantu siswa dalam mencapai kompetensi yang dinginkan. Model desain pengembangan ini memanfaatkan media dan memberdayakan teknologi untuk membantu siswa dalam mencapai tujuan pembelajaran. Pemanfaatan media dan teknologi digunakan untuk menjamin desain pembelajaran yang mampu meningkatkan hasil belajar, memotivasi proses belajar, meningkatkan daya ingat terhadap materi pelajaran atau retensi, dan mendorong siswa untuk dapat mengaplikasikan pengetahuan dan keterampilan yang sedang dipelajari.

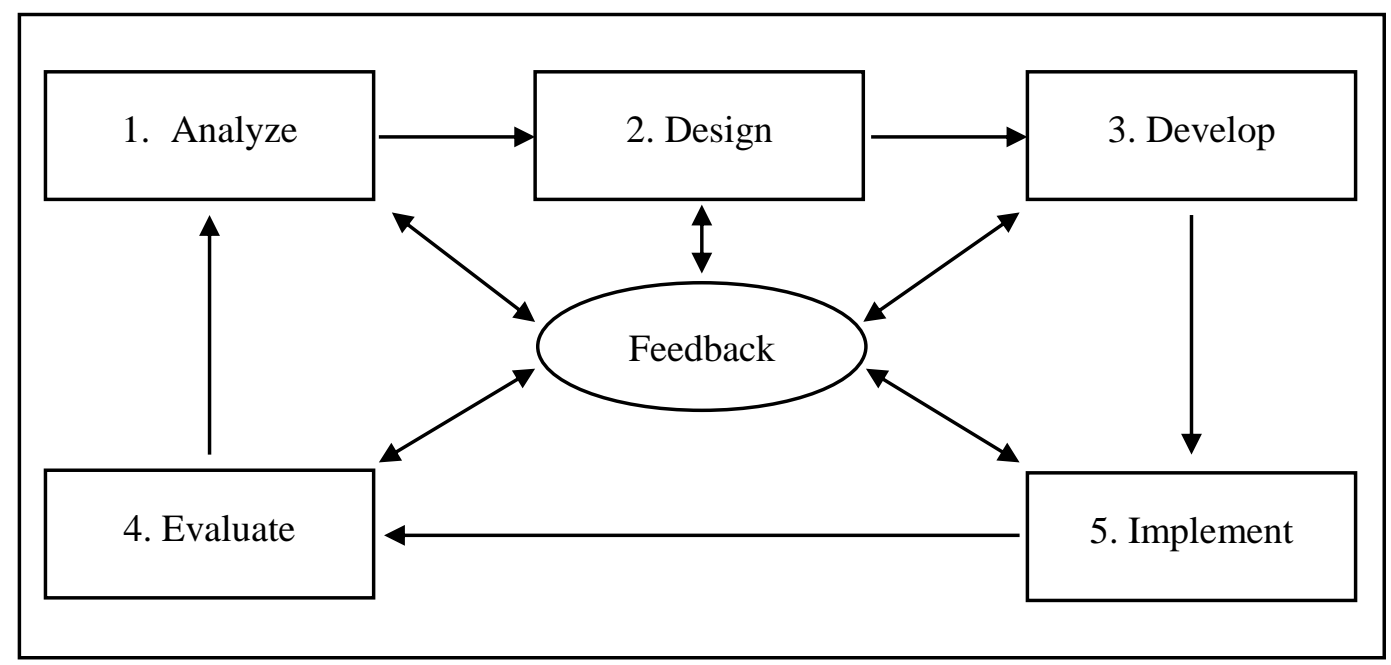

Gambar 1. Model Pengembangan ADDIE (Piskurich, 2000:29)

Berdasarkan gambar 1 uraian tahapan model pengembangan e-modul tematik adalah sebagai sebagai berikut.

a. Analize (Analisis)

Analisis kebutuhan diperlukan untuk membantu proses perancangan dan menganalisis berbagai kebutuhan dan keterbatasan yang ada di lapangan. Tahap ini merupakan tahap pengumpulan data dengan melakukan observasi dan wawancara awal kelapangan pada pembelajaran tematik. Observasi pertama menganalisis penggunaan media dalam pembelajaran, serta kompetensi dasar mata pelajaran tematik. Menentukan strategi pembelajaran yang tepat untuk mengatasi masalah yang ada. Hasil analisis kebutuhan kemudian diolah untuk mengakomodasi berbagai keterbatasan yang ada di lapangan kemudian ditindaklanjuti dengan mendesain pengembangan media yang cocok dan belum pernah di terapkan dalam pembelajaran. 


\section{b. Design (Desain media)}

Pada tahap ini peneliti membuat rencana yang akan dilakukan setelah mendapatkan data awal dari hasil analisis kebutuhan. Proses desain berfokus pada tujuan instruksional yang akan dicapai. Pada tahap ini terdapat langkah yang dilakukan peneliti seperti berikut: 1) menyusun materi pendukung sesuai dengan kebutuhan, 2) menyusun tujuan pembelajaran, 3) menyusun tugas-tugas yang dapat membuat siswa mencapai tujuan pembelajaran, 4) menyiapkan aplikasi untuk mengolah dan membuat program media e-modul, 5) membuat draft prototype produk emodul.

c. Develop (Pengembangan)

Pengembangan merupakan proses membuat atau mengembangkan bahan ajar dan memvalidasinya. Peneliti menggunakan software perangkat lunak dalam membuat e-modul. Hasil produk yang sudah jadi kemudian divalidasi ke ahli media, bahan ajar, dan materi. Tujuan dari proses validasi yaitu untuk menyempurnakan produk e-modul agar dapat digunakan dalam pembelajaran.

\section{d. Implementation (Implementasi)}

Pada tahap implementasi yaitu melakukan ujicoba lapangan. Tahapan ujicoba ini digunakan untuk mengetahui tingkat kepraktisan bahan ajar e-modul. Tingkat kepraktisan yang dimaksud yaitu kemudahan dan kelayakan produk e-modul saat digunakan dalam pembelajaran tematik. Produk e-modul diujicobakan ke pengguna yaitu guru dan siswa kelas IV SD Muhammadiyah 9 Malang. Adapun prosedur pelaksanaan uji coba ke lapangan sebagai berikut: (1) siswa dijelaskan tujuan terkait bahan ajar modul konvensional atau paper modul dan e-modul, (2) penjelasan singkat cara menggunakan e-modul dalam pembelajaran tematik tema selalu berhemat energi, (3) siswa diminta untuk memperhatikan tampilan interface e-modul, kemudian siswa diminta untuk mencoba menjalankan aplikasi e-modul secara mandiri dengan menggunakan perangkat komputer. (4) siswa mempelajari materi dan evaluasi yang ada di dalam e-modul, (5) setelah mempelajari materi, siswa dipersilahkan mengerjakan soal test berupa test mandiri yang terdapat di dalam e-modul, (4) selanjutnya siswa diminta mengisi kuesioner sebagai respon dalam menggunakan e-modul selama pembelajaran berlangsung.

e. Evaluation (Evaluasi)

Untuk mengetahui kualitas produk, maka dilakukan kegiatan evaluasi. Tahap ini dilakukan untuk mengetahui hasil evaluasi secara kualitatif dan kuantitatif. 
Data kualitatif didapatkan dari angket validasi ahli, angket hasil uji coba ke siswa. Data Kuantitatif didapatkan dari hasil skor uji coba yang diperoleh.

Teknik pengumpulan data dalam penelitian ini menggunakan metode 1) observasi dan wawancara awal, digunakan untuk mengetahui analisis kebutuhan awal yang ada di lapangan, 2) angket, digunakan saat uji coba di lapangan untuk mengetahui respon guru maupun siswa ketika proses pembelajaran menggunakan e-modul. Teknik analisis data yang digunakan pada penelitian dan pengembangan ini adalah teknik analisis data deskriptif, yaitu analisis deskriptif kualitatif dan deskriptif kuantitatif.

\section{HASIL DAN PEMBAHASAN}

Penelitian dan pengembangan ini menghasilkan produk akhir berupa bahan ajar modul elektronik (e-modul) pada pembelajaran tematik tema selalu berhemat energi. Produk modul digital (e-modul) ini diuji cobakan di kelas IV SD Muhammadiyah 9 Kota malang. Tujuan ujicoba ini yaitu untuk mengetahui kepraktisan (e-modul) respon pengguna dalam pembelajaran tematik. Selain menghasilkan produk (e-modul), penelitian ini juga menghasilkan buku pedoman penggunaan (e-modul) yang dapat digunakan oleh guru maupun siswa. Buku pedoman berisi petunjuk cara penggunaan dalam menerapkan e-modul dalam pembelajaran tematik.

Hasil penelitian pengembangan e-modul dapat dideskripsikan sebagaimana tahapan ADDIE (Piskurich, 2000:29), adapun rincian tahapan pengembangan produk e-modul dapat dijabarkan sebagai berikut. Tahap analyze, yaitu melakukan analisis kebutuhan di sejumlah sekolah dasar di Kota Malang sebagai dasar untuk pengembangan produk yang meliputi 1) analisis karakteristik siswa, 2) analisis sumber dan media pembelajaran, 3) analisis keberadaan sarana teknologi dan informasi. Dari hasil analisis kebutuhan dihasilkan bahwa di beberapa sekolah dasar terutama SD Muhammadiyah 9 Kota malang sudah memanfaatkan sarana teknologi sebagai media maupun sumber belajar tematik. Media dan bahan ajar yang digunakan menggunakan buku guru dan buku siswa. Lebih lanjut temuan di lapangan belum adanya media/bahan ajar berbasis teknologi yang digunakan dalm pembelajaran. Tahap design, yaitu membuat prototype produk e-modul. Pada tahap ini peneliti membuat rancangan e-modul baik dari segi konten maupun design tampilan spesifikasi produk. Isi atau konten e-modul berisi materi tema selalu berhemat energi dan pembuatan design tampilan e-modul menggunakan aplikasi grafis corel draw $\times 5$. Berikut ini adalah hasil tampilan print screen produk pengembangan modul digital (e-modul). 


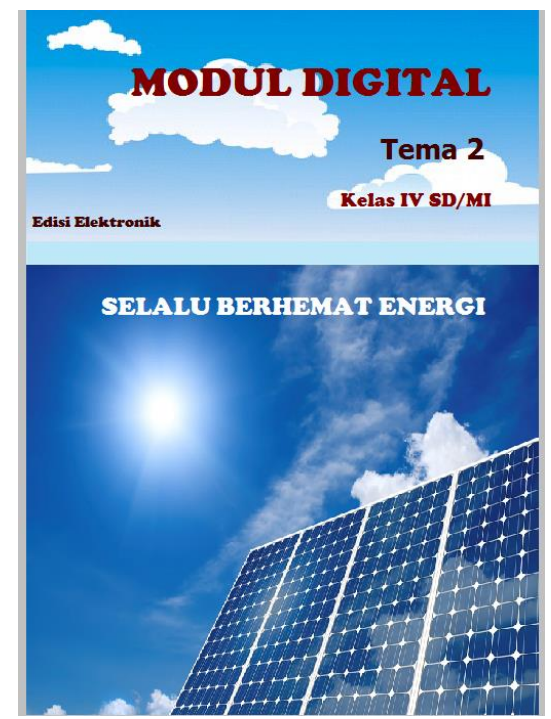

\section{Gambar 2. Tampilan halaman sampul depan e-modul}

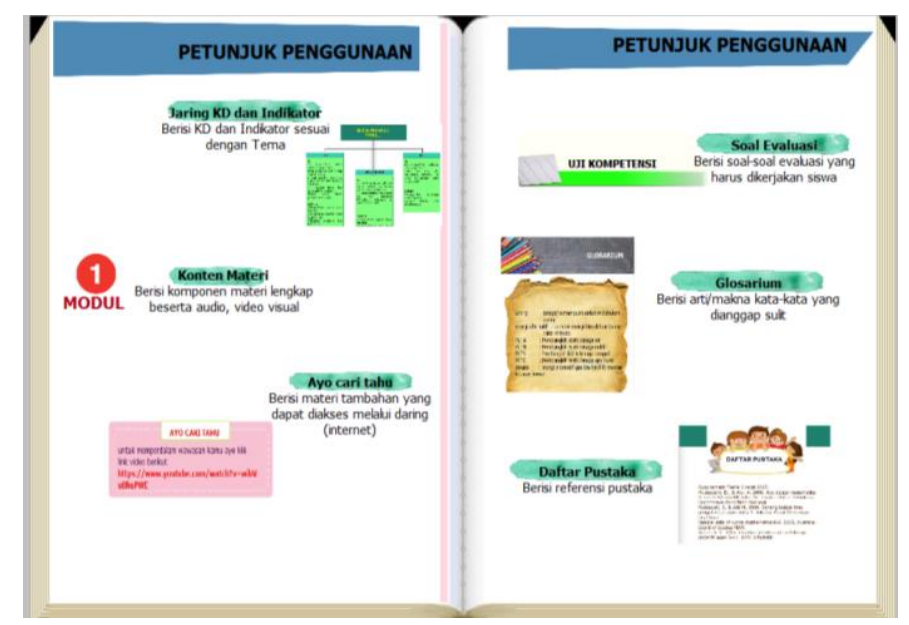

Gambar 3. Tampilan petunjuk dan isi e-modul

Tahap develop, yaitu peneliti melakukan proses pengembangan dari hasil rancangan produk. Pada tahap ini peneliti menggunakan software tambahan untuk menghasilkan produk e-modul secara utuh. Adapun aplikasi/software yang digunakan yaitu DeskTop Author 7.0.1. Software Desktop Author merupakan software yang dapat digunakan untuk membuat produk ebook (buku elektronik) salah satunya juga dapat digunakan untuk membuat e-modul (modul digital). Selanjutnya setelah produk jadi, dilakukan validasi kepada para ahli. Meliputi validasi ahli materi tematik, validasi ahli 
bahasa, validasi ahli media. Tujuan dari validasi yaitu untuk menyempurnakan produk e-modul agar layak digunakan dalam pembelajaran.

Berdasarkan hasil uji coba ahli secara rinci rekapitulasi hasil validasi materi, bahasa dan media dapat dilihat pada Tabel 1 berikut.

Tabel 1. Rekapitulasi Hasil Validasi Materi, Bahasa dan Media

\begin{tabular}{cll}
\hline Validator & \multicolumn{1}{c}{ Hasil } & \multicolumn{1}{c}{ Komentar dan Saran } \\
\hline Materi & $82 \%$, & $\begin{array}{l}\text { Muatan materi tematik lebih diperkaya dengan } \\
\text { mengintegrasikan link internet sebagai tambahan } \\
\text { informasi }\end{array}$ \\
\hline Bahasa & $82,5 \%$ & $\begin{array}{l}\text { Penggunaan tata bahasa sesuai dengan ejaan. } \\
\text { Penggunaan kalimat sederhana }\end{array}$ \\
& kalid perlu revisi & \\
\hline Mecil & $82 \%$, & Tampilan interface sudah bagus, terdapat \\
& Valid perlu revisi & $\begin{array}{l}\text { tombol byperlink dan memuat konten } \\
\text { multimedia (teks, video, suara, dan animasi) }\end{array}$ \\
\hline kecil & $82,17 \%$, valid & $\begin{array}{l}\text { Dapat digunakan dalam pembelajaran dengan } \\
\text { revisi kecil }\end{array}$ \\
\hline rata & & Sotal rata-
\end{tabular}

Sumber: Olahan Angket Validasi Ahli

Berdasarkan tabel 1 dapat dideskripsikan bahwa hasil validasi ahli materi memperoleh persentase $82 \%$ dengan kriteria valid. Saran yang dapat diberikan dari ahli materi yaitu muatan materi tematik lebih diperkaya dengan mengintegrasikan link internet sebagai tambahan informasi. Hasil validasi ahli bahasa memperoleh persentase 82,5\% dengan kriteria valid. Saran yang dapat diberikan dari ahli bahasa yaitu Penggunaan tata bahasa sesuai dengan ejaan. Penggunaan kalimat sederhana. Lebih lanjut hasil validasi ahli media memperoleh persentase $82 \%$ dengan kriteria valid. Adapun saran dari ahli media yaitu Tampilan interface sudah bagus, terdapat tombol byperlink dan memuat konten multimedia (teks, video, suara, dan animasi). Hal ini senada dengan Rusman (2013:72) bahwa komponen bahan ajar berbasis komputer memuat dukungan adanya link yang menghubungkan dengan informasi. Dapat dikatakan dengan adanya byperlink dapat mendukung kompleksitas materi yang disajikan dalam bahan ajar e-modul. Artinya siswa dapat mengakses tambahan informasi materi melalui jaringan internet atau youtube yang sudah tersedia, sehingga wawasan siswa juga bertambah. 


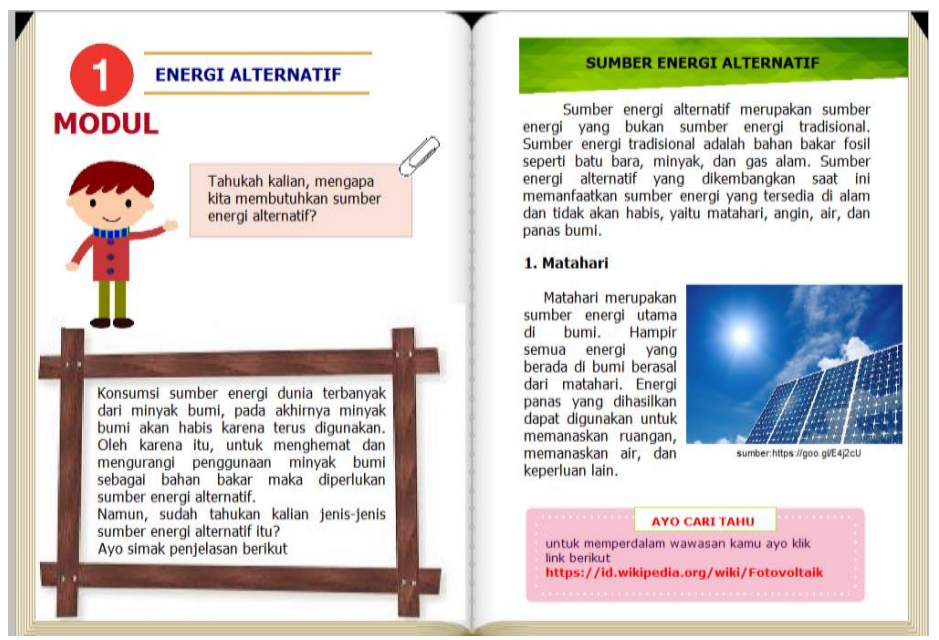

Gambar 4. Tampilan halaman byperlink e-modul

Setelah didapat hasil kevalidan materi, kevalidan bahasa, dan kevalidan media, selanjutnya dilakukan pengambilan rata-rata untuk mengetahui hasil akhir tingkat kevalidan produk e-modul secara umum. Hasil tingkat kevalidan e-modul mencapai persentase 82,17\%, artinya produk e-modul pada pembelajaran tematik selalu berhemat energi dengan kriteria valid atau layak digunakan dalam pembelajaran.

Tahap ke empat dan kelima dari pengembangan produk merupakan tahap implementation dan evaluation, yaitu tahap uji coba pengguna kepada guru dan siswa. Tujuan dari tahap ini yaitu untuk mengetahui kepraktisan dari penggunaan e-modul dalam pembelajaran sekaligus mengevaluasi dari penerapan e-modul . Data kepraktisan ujicoba e-modul diperoleh dari guru dan siswa kelas IV SD Muhammadiyah 9 Kota Malang melalui uji coba lapangan. Secara rinci rekapitulasi hasil uji coba lapangan untuk mengukur tingkat kepraktisan produk dapat dilihat pada Tabel 2 berikut.

Tabel 2. Rekapitulasi Hasil Ui Coba Lapangan e-Modul

\begin{tabular}{|c|c|c|c|}
\hline $\begin{array}{l}\text { Komponen } \\
\text { yang dinilai }\end{array}$ & $\begin{array}{l}\text { Subjek Uji } \\
\text { Coba }\end{array}$ & Temuan & Keterangan \\
\hline \multirow{7}{*}{ Kepraktisan } & \multirow{6}{*}{$\begin{array}{l}\text { Guru } \\
83 \% \\
\text { Praktis }\end{array}$} & & 1. E-modul mudah digunakan dan \\
\hline & & & lebih mudah dari membaca \\
\hline & & Hasil & buku \\
\hline & & Akhir & 2. Desain e-modul menarik karena \\
\hline & & $86,5 \%$ & seperti buku 3 dimensi \\
\hline & & Praktis & $\begin{array}{l}\text { 3. Materi sudah dilengkapi gambar } \\
\text { dan video yang menarik }\end{array}$ \\
\hline & Siswa & & 1. Siswa mudah memahami materi \\
\hline
\end{tabular}




\begin{tabular}{|c|c|c|c|}
\hline $\begin{array}{l}\text { Komponen } \\
\text { yang dinilai }\end{array}$ & $\begin{array}{c}\text { Subjek Uji } \\
\text { Coba }\end{array}$ & Temuan & Keterangan \\
\hline & $90 \%$ & & menggunakan e-modul \\
\hline & Praktis & & $\begin{array}{l}\text { 2. Siswa termotivasi menggunakan } \\
\text { e-modul karena tombolnya } \\
\text { tidak rumit }\end{array}$ \\
\hline
\end{tabular}

\section{Sumber: Olahan Angket Guru dan Siswa}

Berdasarkan Tabel 2 diperoleh rekapitulasi hasil analisis uji coba produk yang menunjukkan tingkat kepraktisan produk mencapai 86,5\% kriteria praktis. Berdasarkan hasil analisis yang sudah dipaparkan, dapat dikatakan bahwa hasil uji validasi dan uji coba lapangan produk e-modul memiliki kualitas yang tinggi atau layak digunakan dalam pembelajaran di kelas IV sekolah dasar. Hal ini sejalan dengan Nieveen (1997:127) dan Akker (1999:10) suatu perangkat komputer untuk pembelajaran, dapat dikatakan memiliki kualitas yang tinggi jika mencakup karakteristik kevalidan (validity), kepraktisan (practicality), dan keefektifan (effectiveness). Berdasarkan hasil respon siswa dapat dikatakan penggunaan e-modul mampu menarik perhatian dan motivasi siswa karena siswa mudah memahami materi menggunakan e-modul. Hal ini sejalan dengan pendapat Barron (2002:4) bahwa penerapan teknologi interaktif dalam lingkungan pembelajaran mampu membangkitkan semangat dalam proses pembelajaran. Hal tersebut didukung hasil penelitian Putra (2017:47) bahwa e-modul yang berbasis model pembelajaran discovery learning membantu siswa dan guru dalam memahami materi dan menambah sumber belajar siswa. Lebih lanjut berdasarkan hasil respon guru bahwa emodul mudah digunakan dalam pembelajaran dari pada menggunakan buku. Hal ini sejalan dengan hasil penelitian Zulvianda, 2016 bahwa penerapan materi pada e-module mudah dipahami daripada membaca buku, menarik dan tidak membosankan, dan penyampaian bahasanya jelas. Berdasarkan hasil respon guru dan siswa dapat disimpulkan bahwa penggunaan e-modul mudah digunakan karena bersifat user-friendly dengan dukungan konten e-modul terintegrasi dengan link internet web based learning.

\section{SIMPULAN}

Berdasarkan hasil kajian produk yang sudah dihasilkan dapat disimpulkan bahwa bahan ajar e-modul dikembangkan melalui beberapa tahapan yaitu perencangan (design), pengembangan (develop), implementation (penerapan) dan evaluasi (evaluate). Hasil validasi ahli materi memperoleh persentase $82 \%$ dengan kriteria valid. Hasil validasi ahli bahasa memperoleh persentase 82,5\% dengan kriteria valid dan hasil 
validasi ahli media memperoleh persentase $82 \%$ dengan kriteria valid. Hasil ujicoba respon pengguna e-modul dalam pembelajaran menunjukkan tingkat kepraktisan produk mencapai $86,5 \%$ kriteria praktis. Respon guru dan siswa menunjukkan emodul praktis dan membantu dalam pembelajaran tematik, e-modul dapat digunakan secara mandiri oleh siswa dengan menggunakan peralatan berbasis komputer. Untuk mendukung eksplorasi komponen materi yang lebih komplek, pengguna (user) dapat mengintegrasikan e-modul dengan link internet. E-modul tematik dilengkapi dengan teks, animasi, gambar, dan video sebagai materi pendukung. Untuk mengakomodasi kemadirian siswa dalam belajar, e-modul juga dilengkapi dengan soal evaluasi sebagai bahan refleksi siswa selama belajar menggunakan e-modul tematik. Bahan ajar e-modul direkomendasikan dapat digunakan dalam skala yang lebih luas melalui implementasi dan diseminasi di sekolah yang berbeda. Bagi peneliti lain dapat mengembangakn lebih lanjut menggunakan perangkat yang dapat terintegrasi dengan smartphone yang tidak terbatas pengunaannya pada komputer. Tahap pengujian kelayakan produk sebaiknya tidak hanya dilakukan pada satu sekolah agar kualitas produk semakin meningkat.

\section{DAFTAR PUSTAKA}

Arkün, S. \& Akkoyunlu, B. 2008. A Study on the Development Process of a Multimedia Learning Environment According to the ADDIE Model and Students' Opinions of the Multimedia Learning Environment. Interactive Educational Multimedia University of Barcelona, (17)

Barron, Ann E. 2002. Technologies For Education A Practical Guide Fourth Edition. A Division of Greenwood Publishing Group, Inc. Greenwood Village, Colorado

Dalal, M. 2014. Impact of E-modul Tutorials in a Computer Science Laboratory Course-An Empirical Study. The Electronic Journal of e-Learning, 12 (4)

Depdiknas. 2008. Panduan Pengembangan Bahan Ajar. Jakarta: Direktorat Jendral Pendidikan Dasar dan Menengah

Jonias, Hendri. 2014. Pengembangan Media Pembelajaran E-Module Terhadap Prestasi Belajar Siswa dalam Mata Pelajaran Muatan Lokal Elektronika di SMPN 6 Surabaya. Jurnal Pendidikan Teknik Elektro. Volume 03 Nomor 03. Hlm. 645-649

Kemdikbud. 2017. Materi Pendukung Literasi Digital. Jakarta: Kementerian Pendidikan dan Kebudayaan 
Nieveen, N.1999. Prototyping to Reach Product Quality. In J. van de Akker, R. Branch, K. Gustafson, N. Nieveen \& T. Plomp (Eds.) Design Approaches and Tools in Education and Training (pg. 125-136). Dordrecht, The Netherlands: Kluwer Academic Publishers

Piskurich, George M. 2000. The ASTD Handbook of Training Design and Delivery : A Comprehensive Guide to Creating and Delivering Training Programs, Instructor-led, Computer-based, or Self-directed. United States: McGraw-Hill Professional

Prastowo, A. 2013. Pengembangan Bahan Ajar Tematik Panduan Lengkap Aplikatif. Yogyakarta: Diva Press

Pribadi, Benny. A. 2011. Model Assure untuk Mendesain Pembelajaran Sukses. Jakarta: Dian Rakyat.

Putra, Komang Wisnu Baskara,dkk. 2017. Pengembangan E-Modul Berbasis Model Pembelajaran Discovery Learning Pada Mata Pelajaran "Sistem Komputer" Untuk Siswa Kelas X Multimedia SMK Negeri 3 Singaraja. Jurnal Pendidikan Teknologi dan Kejuruan Vol. 14, No.1. Hlm. 40 - 49

Rusman, Kurniawan, D., \& Rinaya, C. 2013. Pembelajaran Berbasis Teknologi Informasi dan Komunikasi Mengembangkan Profesionalitas Guru. Jakarta: Raja Grafindo Persada

Smaldino, S. E., Lowther, D.L., Russell, J.D. 2008. Teknologi Pembelajaran dan Media untuk Belajar (edisi ke-9). Terjemahan Arif Rahman. 2011. Jakarta: Kencana Prenada Media Group

Syamsudin. 2005. Psikologi Pendidikan dan Perkembangan.Yogya: Rineka Cipta 2

Zulvinda, Haris, dkk. 2016. Pengembangan E-Module Kimia SMA Pada Materi Larutan Elektrolit dan Non Elektrolit. Jurnal Ilmiah Mahasiswa Pendidikan Kimia (JIMPK) Vol 1. No. 3. Hlm 9-16 